\title{
Is fibrinogen plasma level a risk factor for the first 24-hour death of medically treated acute type A aortic dissection patients?
}

\author{
Zeyi Cheng ${ }^{1}$, Honghui Wang ${ }^{2}$ \\ ${ }^{1}$ Department of Cardiovascular Surgery, West China Hospital, Sichuan University, Chengdu, China; ${ }^{2}$ Department of Traumatology and General \\ Surgery, Chun'an County Hospital of Traditional Chinese Medicine, Hangzhou, China \\ Correspondence to: Honghui Wang. Department of Traumatology and General Surgery, Chun'an County Hospital of Traditional Chinese Medicine, \\ No. 1 Xin'an West Road, Qianhu Island, Chun'an County, Hangzhou, China. Email: ch20588@163.com. \\ Response to: Yang S, Xue Y, Liu J, et al. Is fibrinogen plasma level a risk factor for the first 24-hour death of medically treated acute type A aortic \\ dissection patients? Ann Transl Med 2020;8:1015.
}

Submitted Sep 23, 2020. Accepted for publication Nov 08, 2020.

doi: $10.21037 /$ atm-20-6585

View this article at: http://dx.doi.org/10.21037/atm-20-6585

We have read with great interest the article titled "Is fibrinogen plasma level a risk factor for the first 24-hour death of medically treated acute type A aortic dissection patients?" by Sheng Yang (1). The article pointed that ATAAD patients with a fibrinogen plasma level of $>4.0 \mathrm{~g} / \mathrm{L}$ have lower first 24-hour mortality when treated medically, while patients with a fibrinogen plasma level of $\leq 4.0 \mathrm{~g} / \mathrm{L}$ are more likely to die without surgery in the first 24 hours.

In this article, the authors analyzed many clinical characteristics like age, sex, blood pressure, et al., but they didn't collect patient's eating habits, daily physical activities, triglycerides level, low-density lipoprotein and highdensity lipoprotein data, because all those factors can affect fibrinogen plasma level in plasma.

High-fat diet and hyperlipidemia can lead to increased fibrinogen levels, Halle et al. (2) reported when in hyperlipidemia, especially hypertriglyceridemia, the increase in the synthesis of very low-density lipoprotein in the liver is also accompanied by an increase in the synthesis of coagulation factors, lipoprotein can activate the coagulation factor after contacting it, blood is in hypercoagulable state. Proper exercise can reduce fibrinogen levels, Montgomery et al. (3) observed the fibrinogen levels of 156 male soldiers during military training, they found that the level of fibrinogen was significantly reduced and the death rate from cardiovascular disease was also relatively low, so we believe it is better to add those parameters in order to draw a more accurate conclusion, otherwise, they could constitute confounding bias, subgroup analysis and further discuss could draw a more rigorous conclusion.

\section{Acknowledgments \\ Funding: None.}

\section{Footnote}

Provenance and Peer Review: This article was a free submission to the journal. The article has undergone external peer review.

Conflicts of Interest: The authors have completed the ICMJE uniform disclosure form (available at http://dx.doi. org/10.21037/atm-20-6585). The authors have no conflicts of interest to declare.

Ethical Statement: The authors are accountable for all aspects of the work in ensuring that questions related to the accuracy or integrity of any part of the work are appropriately investigated and resolved.

Open Access Statement: This is an Open Access article distributed in accordance with the Creative Commons Attribution-NonCommercial-NoDerivs 4.0 International License (CC BY-NC-ND 4.0), which permits the noncommercial replication and distribution of the article with the strict proviso that no changes or edits are made and the original work is properly cited (including links to both the 
formal publication through the relevant DOI and the license). See: https://creativecommons.org/licenses/by-nc-nd/4.0/.

\section{References}

1. Yang S, Xue Y, Liu J, et al. Is fibrinogen plasma level a risk factor for the first 24-hour death of medically treated acute type A aortic dissection patients? Ann Transl Med 2020;8:1015

Cite this article as: Cheng $\mathrm{Z}$, Wang $\mathrm{H}$. Is fibrinogen plasma level a risk factor for the first 24-hour death of medically treated acute type A aortic dissection patients? Ann Transl Med 2020;8(23):1619. doi: 10.21037/atm-20-6585
2. Halle M, Berg A, Keul J, et al. Association between serum fibrinogen concentrations and HDL and LDL subfraction phenotypes in healthy men. Arterioscler Thromb Vasc Biol 1996;16:144-8.

3. Montgomery HE, Clarkson P, Nwose OM, et al. The acute rise in plasma fibrinogen concentration with exercise is influenced by the G-453-A polymorphism of the beta-fibrinogen gene. Arterioscler Thromb Vasc Biol 1996;16:386-91. 